\title{
Expression and characterization of cecropinXJ, a bioactive antimicrobial peptide from Bombyx mori (Bombycidae, Lepidoptera) in Escherichia coli
}

\author{
LIJIE XIA ${ }^{1}$, FUCHUN ZHANG ${ }^{1}$, ZHONGYUAN LIU ${ }^{1}$, JI MA ${ }^{1}$ and JIANHUA YANG ${ }^{2}$ \\ ${ }^{1}$ Xinjiang Key Laboratory of Biological Resources and Genetic Engineering, \\ College of Life Science and Technology, Xinjiang University, Urumqi, Xinjiang 830046, P.R. China; \\ ${ }^{2}$ Department of Pediatrics, Section of Hematology/Oncology, Baylor College of Medicine, Houston, TX 77030, USA
}

Received January 9, 2013; Accepted March 22, 2013

DOI: $10.3892 / \mathrm{etm} .2013 .1056$

\begin{abstract}
Insect antimicrobial peptides (AMPs) have a broad antimicrobial spectrum. To aid the characterization of the gene function and further applications, we cloned the gene of cecropinXJ into the prokaryotic expression vector pET32a and expressed cecropinXJ in Escherichia coli BL21 (DE3). Following induction by isopropyl- $\beta$-D-thiogalactoside (IPTG), a $25 \mathrm{kDa}$ fusion peptide of cecropinXJ with a tagged thioredoxin (Trx) protein was highly expressed in E. coli. The yield was $10 \mathrm{mg} / \mathrm{l}$ culture medium following purification on nickel-nitrilotriacetic acid (Ni-NTA) metal affinity chromatography matrices. The purified recombinant antibacterial peptide, cecropinXJ, retained a high stability against Staphylococcus aureus over a temperature range from 4 to $100^{\circ} \mathrm{C}$ and a $\mathrm{pH}$ range from $\mathrm{pH} 2.0$ to 12.0 . The minimum inhibitory concentration (MIC) of the fusion protein against $S$. aureus was $0.4 \mu \mathrm{M}$. The recombinant cecropinXJ is also cytotoxic to several types of human cancer cells.
\end{abstract}

\section{Introduction}

Antimicrobial peptides (AMPs) are a class of immune-related peptides that provide the first line of defense to protect the host from invading pathogens (1). These peptides prevent bacterial infections and are particularly critical for invertebrates, such as insects, that lack lymphocytes and antibodies (2). AMPs have minimal toxicity and low sensitivity effects to the host (3). Thus, antimicrobial peptides may be applied in

Correspondence to: Professor Fuchun Zhang, Xinjiang Key Laboratory of Biological Resources and Genetic Engineering, College of Life Science and Technology, Xinjiang University, 14 Shengli Road, Urumqi, Xinjiang 830046, P.R. China E-mail: zfcxju@xju.edu.cn

Key words: prokaryotic expression, antimicrobial peptide, antibacterial activity, antitumor activity medicine, agriculture and food as new and safe antibiotics or antiseptic agents (4-7).

Cecropins, a group of small basic polypeptides mainly found in the hemolymph of insects, consist of 31-39 amino acid residues and have a broad spectrum, high heat stability and potent bacteriostatic activity (8-10). Eukaryotic cell expression or artificial synthesis of the cecropin gene is characterized by a low efficiency and high cost (11-13). In order to explore a cost-effective and scalable method for producing large quantities of active peptides, expression of recombinant peptides may be used. To date, various expression systems, including yeast (14), E. coli (15) and insect cells (16), have been established for the production of recombinant antibacterial proteins.

In recent years, studies concerning the expression of antimicrobial peptides have mainly focused on the use of fusion partners (17). Thioredoxin, a heat-stable and low molecular weight soluble protein in the prokaryotic cytoplasm, has been shown to display chaperone-like activity (18). Fusion proteins of antimicrobial peptides generated in E. coli reduce the toxic effect of antimicrobial peptides to the host cells and protect the small antimicrobial peptides from proteolytic degradation.

CecropinXJ, is a member of the cecropin family, which we first cloned from the larvae of the Xinjiang silkworm (Bombyx mori) by reverse transcription-polymerase chain reaction (RT-PCR) and 3'- and 5'- rapid amplification of cDNA ends (3'/5'-RACE). The complete amino acid sequence of the molecule was determined (19). In addition, we successfully expressed cecropinXJ in Pichia pastoris, where the expression levels were observed to be relatively low (20).

In the present study, we aimed to express cecropinXJ in a prokaryotic expression system, which combines the advantages of high expression levels, easy scale-up and inexpensive growth media. A vector derived from the commercial pET32a(+) was developed. This expression vector carrying the thioredoxin ( Trx) gene and $\mathrm{T} 7$ promoter contained a 6xHis-tag to facilitate purification and enhance the expression yields of fusion proteins in E. coli. We constructed a recombinant expression vector pET32a-cecropinXJ and expressed recombinant cecropinXJ at high levels. A high yield of soluble recombinant cecropinXJ was obtained and purified. The purified recombinant cecropinXJ displayed strong antimicrobial 
activity to bacteria and fungi, as well as cytotoxicity to several types of human cancer cells.

\section{Material and methods}

Bacterial strains, vectors and enzymes. The prokaryotic plasmid pET32a(+) was purchased from Invitrogen (Beijing, China). The restriction enzymes, T4 DNA ligase, DNA ladder and pre-stained protein marker were purchased from Fermentas (Vilnius, Lithuania). E. coli DH (5 $\alpha)$ and BL21(DE3) pLYsS competent cells were purchased from Takara (Dalian, China). PCR primers were synthesized by Shanghai Sangon Biological Engineering Technology \& Services Co., Ltd. (Shanghai, China). Other reagents were obtained either from Sangon Chemical Reagent (Shanghai, China) or Sigma (St. Louis, MO, USA). The test microorganisms used in this study were obtained from the China General Microbiological Culture Collection Center (Beijing, China).

Construction of recombinant pET32a-cecropinXJ expression vector. The sequence of the cecropinXJ gene was amplified and isolated from the plasmid pMD18-T-cecropinXJ (19), which carries the cDNA of cecropinXJ from the Xinjiang silkworm larvae (Bombyx mori). The upstream primer $\mathrm{Pl}$, 5'-CCG gaa ttc AGG TGG AAG ATC TTC AAG AAA ATT GAA AAA ATG GGC-3' contained an EcoRI site (lower case), and the downstream primer P2, 5'-CCG ctc gag TCA TTT TCC TAT AGC TTT AGC CGA ACC AAG-3' contained a XhoI site (lower case). The PCR reaction parameters were: pre-denaturation at $95^{\circ} \mathrm{C}$ for $1 \mathrm{~min}$, denaturation at $95^{\circ} \mathrm{C}$ for $1 \mathrm{~min}$, annealing at $95^{\circ} \mathrm{C}$ for $30 \mathrm{sec}$, extension at $55^{\circ} \mathrm{C}$ for $1 \mathrm{~min}$ for 30 cycles and $1 \mathrm{~min}$ extension at $72^{\circ} \mathrm{C}$. The cecropinXJ gene and the vector pET32a plasmid were subjected to digestion with EcoRI and XhoI, and ligated using T4 DNA ligase. The recombinant pET32a-cecropinXJ was transformed into $E$. coli $\mathrm{DH}(5 \alpha)$ competent cells for amplification. Positive colonies resistant to ampicillin on a Luria-Bertani (LB) plate were selected and the plasmid pET32a-cecropinXJ was confirmed by restriction enzyme mapping and DNA sequencing.

Expression of recombinant protein. The recombinant plasmid pET32a-cecropinXJ was transformed into $E$. coli BL21(DE3) competent cells for expression. The expression of the fusion protein was induced by the addition of $0.8 \mathrm{mM}$ isopropyl- $\beta$-D-thiogalactoside (IPTG) once the optical density at $600 \mathrm{~nm}\left(\mathrm{OD}_{600}\right)$ of the culture had reached 0.6-0.8. After $5 \mathrm{~h}$ of induction, $1 \mathrm{ml}$ culture was centrifuged at 8,000 $\mathrm{x}$ for $5 \mathrm{~min}$. The cell pellet was resuspended in $100 \mu 1$ phosphate-buffered saline (PBS) and analyzed by Tricine-SDS-PAGE. The expression level of recombinant cecropinXJ was determined by protein bands and quantified using densitometry (GeneTools software, Philomath, OR, USA). Bovine serum albumin (BSA) was used as a standard.

Purification of recombinant protein. Following induction, 11 culture was centrifuged at 8,000 x g for $5 \mathrm{~min}$. The pellet was resuspended in $10 \mathrm{ml} \mathrm{PBS}$ and placed in an ice bath for ultrasonic lysis $(200 \mathrm{~W}, 5 \mathrm{sec}, 5 \mathrm{sec})$. The supernatant was further purification by $80 \%$ ammonium sulphate fraction- ation, dialysis and desalt, filtered using a $0.22 \mu \mathrm{m}$ filtration membrane and loaded onto a Ni-NTA agarose column (Qiagen, Hilden, Germany). Using the QIAexpressionist ${ }^{\mathrm{TM}}$ kit, the supernatant was mixed with equilibration buffer $(50 \mathrm{mM}$ sodium phosphate; $\mathrm{pH}$ 8.0; $0.3 \mathrm{M}$ sodium chloride; and $10 \mathrm{mM}$ imidazole) gently by agitation (150 rpm on a rotary shaker) at $4^{\circ} \mathrm{C}$ for $60 \mathrm{~min}$. The column was washed with buffer (equilibration buffer) and the protein was eluted with elution buffer (50 mM sodium phosphate; $\mathrm{pH} 8.0 ; 0.3 \mathrm{M}$ sodium chloride; and $250 \mathrm{mM}$ imidazole). The eluate was concentrated through a $10 \mathrm{kDa}$ cutoff Centriprep filter (Millipore, Bedford, CA, USA) for Tricine-SDS-PAGE and western blot analysis.

Western blot analysis. The concentration of purified recombinant protein was detected using a Bradford protein assay kit. The supernatants were electrophoresed using $15 \%$ Tricine-SDS-PAGE and transferred onto a PVDF membrane (Pall Corporation, Washington, NY, USA). After being washed with TBST buffer (20 mM Tris- $\mathrm{HCl}, 150 \mathrm{mM} \mathrm{NaCl}$ and $0.05 \%$ Tween 20), the membrane was blocked with $3 \%$ (v/v) BSA in TBST buffer overnight at $4^{\circ} \mathrm{C}$. The membrane was washed three times for 5 min each time with TBST buffer and incubated with $1 \%(\mathrm{v} / \mathrm{v}) \mathrm{BSA}$ in TBS buffer for $2 \mathrm{~h}$ at $37^{\circ} \mathrm{C}$ with specific anti-His-tag antibodies $(1: 1,000)$. The membranes were washed three times with TBST buffer and incubated with HRP-conjugated secondary antibodies (Invitrogen, Grand Island, NY, USA) at $37^{\circ} \mathrm{C}$ for $1 \mathrm{~h}$. After washing three times with TBST buffer, the membrane was analyzed using the DAB substrate kit (Invitrogen).

Assay of antimicrobial activity. Antimicrobial activity against standard and clinically isolated microorganism strains was analyzed by an inhibition zone assay. The bacteria were grown in $\mathrm{LB}$ broth at $37^{\circ} \mathrm{C}$. A bacterial dilution $\left(100 \mu \mathrm{l} ; \mathrm{OD}_{600}=0.5\right)$ was taken and added to $6 \mathrm{ml}$ fresh LB broth with $0.8 \%$ agar and poured over a $9.0 \mathrm{~cm}$ Petri dish, giving an agar depth of $1 \mathrm{~mm}$. When the top agar had hardened, a $10 \mu \mathrm{l}$ aliquot of test sample filtered through a $0.22-\mu \mathrm{m}$ filter (Millipore) was dropped onto the surface of the top agar and incubated at $37^{\circ} \mathrm{C}$ overnight. If the sample examined had antimicrobial activity, a clear zone was formed on the surface of the top agar representing inhibition of bacterial growth. The minimal inhibitory concentration (MIC) was determined in liquid medium according to the method described by Wang et al (21). The MIC was determined from three independent experiments performed in triplicate.

Assay of antifungal activity. The fungi were cultivated on potato/dextrose/agar (PDA) media at $28^{\circ} \mathrm{C}$. After 6 days, the non-germinate conidia were inoculated into sterile water. Samples of $\sim 2 \times 10^{4}$ cells $/ \mathrm{ml}$ each of Alternaria alternata, Penicillium digitatum, Botrytis cinerea, Rhizopus stolonifer, Penicillium italicum and Magnaporthe grisea were seeded in yeast extract peptone dextrone (YPD) media to a final volume of $100 \mu \mathrm{l}$, in a flat-bottom 96 -well microtiter plate. A two-fold dilution series of cecropinXJ solutions $(100,50,25,12.5,6.25$, $3.125,1.56,0.78$ and $0.39 \mu \mathrm{M})$ were added to the plates and kept at $28^{\circ} \mathrm{C}$ for $24 \mathrm{~h}$. A total of $10 \mu 15 \mathrm{mg} / \mathrm{ml} \mathrm{3-(4,5-dimethyl-}$ 2-thiazolyl)-2,5-diphenyl-2H-tetrazolium bromide (MTT) solution in PBS (pH 7.4) was added to each well and the plates were incubated for $4 \mathrm{~h}$. Fungal growth was analyzed using a 
Table I. Isolation of recombinant cecropinXJ based on 11 of bacterial culture.

\begin{tabular}{lccc}
\hline Purification step & Total protein $(\mathrm{g})$ & TrxA-cecropinXJ $(\mathrm{g})$ & Purity $(\%)^{\mathrm{c}}$ \\
\hline Sonicated supernatant & $1.147 \pm 0.614^{\mathrm{a}}$ & $0.998 \pm 0.215^{\mathrm{b}}$ & Not applicable \\
Ammonium sulfate precipitation & $0.715 \pm 0.347^{\mathrm{a}}$ & $0.429 \pm 0.208^{\mathrm{b}}$ & $>60$ \\
HisTrap & $0.016 \pm 0.003^{\mathrm{a}}$ & $0.015 \pm 0.002^{\mathrm{c}}$ & $>90$ \\
\hline
\end{tabular}

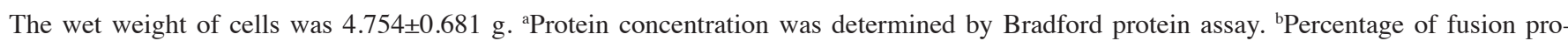
tein (TrxA-cecropinXJ) from total proteins was estimated by Tricine-SDS-PAGE gel scanning. 'Purity of protein was estimated by staining Tricine-SDS-PAGE gel with Coomassie blue.

microplate reader at $570 \mathrm{~nm}$. Assays were performed in triplicate for three independent experiments.

Effect of $\mathrm{pH}$ and temperature on cecropinXJ activity. The stability of the purified cecropinXJ at different $\mathrm{pHs}$ and temperatures was evaluated. To determine $\mathrm{pH}$ and temperature resistance, the purified peptide was incubated at various $\mathrm{pH}$ values between 2.0 and 12.0 and temperatures between 4 and $100^{\circ} \mathrm{C}$ for $1-12 \mathrm{~h}$ prior to confirming the antimicrobial activity.

Hemolysis assays. The hemolysis activity of the peptide was assessed by measuring the release of hemoglobin from human red blood cells as reported previously (22). Serial dilutions of the peptides were used and after incubation for $1 \mathrm{~h}$ at $37^{\circ} \mathrm{C}$, the cells were centrifuged and the absorbance of the supernatant was measured at $595 \mathrm{~nm}$. Controls for $0 \%$ hemolysis (blank) and $100 \%$ hemolysis were determined using PBS buffer and $1 \%$ Triton X-100, respectively.

Cell proliferation assay. Cancer cells and $293 \mathrm{~T}$ cells in the logarithmic growth phase $\left(1 \times 10^{5}\right.$ cells $\left./ \mathrm{ml}\right)$ were plated independently into a 96 -well plate $\left(1 \times 10^{4}\right.$ cells per well), then incubated at $37^{\circ} \mathrm{C}$ for $24 \mathrm{~h}$. The media were replaced with $200 \mu \mathrm{l}$ fresh complete medium containing various concentrations of cecropinXJ and complete medium without cecropinXJ was used as a blank control. After another $24 \mathrm{~h}$, the cells were incubated with $20 \mu \mathrm{l}$ MTT solution $(0.5 \mathrm{mg} / \mathrm{ml})$ and $80 \mu \mathrm{l}$ culture medium followed by incubation at $37^{\circ} \mathrm{C}$ for $4 \mathrm{~h}$. Subsequently, $100 \mu 1$ dimethyl sulfoxide was added to dissolve the formazan crystals formed. The OD of the samples was measured with a spectrophotometer at $570 \mathrm{~nm}$. Experiments were performed at least three times. The cell survival was calculated as follows: Cell viability $(\%)=\mathrm{OD}_{570 \text { (sample) }} / \mathrm{OD}_{570 \text { (control) }} \times 100$.

Statistical analysis. All measurement results are expressed as mean \pm standard error (SE) and performed at least three separate times. The differences between the peptide-treated group and control group were evaluated using the unpaired Student's t-test using one-way ANOVA by GraphPad Prism 4 software (La Jolla, CA, USA). P<0.05 was considered to indicate a statistically significant result.

\section{Results}

Expression and purification of recombinant cecropinXJ. The expected molecular masses of 114 and 5700 bp were
A
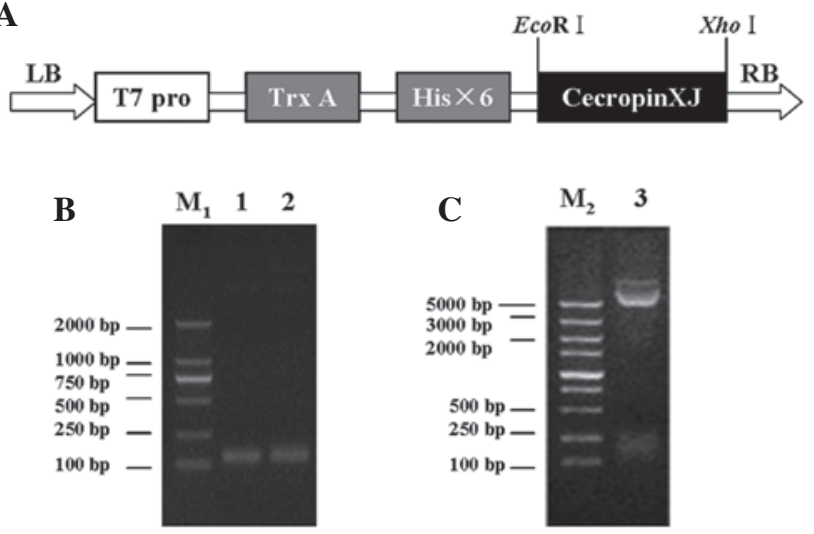

Figure 1. Identification of the recombinant plasmid. (A) Schematic structure of pET32a-cecropinXJ. T7 Pro, T7 promoter; LB and RB, left and right border of the expression vector pET32a. (B) Identification of recombinant plasmid by plasmid polymerase chain reaction (PCR). Lane $\mathrm{M}_{1}$, DNA molecular weight standards; lane 1, PCR product of the cecropinXJ gene fragment with the recombinant plasmid pMD18-T-cecropinXJ as template; lane 2 , PCR product of the cecropinXJ gene fragment with the recombinant plasmid pET32a-cecropinXJ as template. (C) Identification of recombinant plasmid pET30a-cecropinXJ by digestion with EcoRI and XhoI. Lane $\mathrm{M}_{2}$, DNA molecular weight standards; lane 3, DNA fragment of pET32a-cecropinXJ digested with EcoRI and XhoI. PCR,

obtained for the pET32a-cecropinXJ plasmid following digestion with EcoRI and XhoI (Fig. 1). The verified pET32a-cecropinXJ plasmid was then transformed into the E. coli strain BL21(DE3) that encodes a chromosomal T7 RNA polymerase under the control of a tac promoter. Under IPTG induction, the tac promoter is activated and drives expression of pET32a-cecropinXJ. IPTG at a concentration of $0.8 \mathrm{mmol} / 1$ efficiently induced the expression of cecropinXJ in the pET32a-cecropinXJ-BL21(DE3) system at $37^{\circ} \mathrm{C}$, and whole cell proteins were collected for Tricine-SDS-PAGE gel analysis. A major band at the expected size of $25 \mathrm{kDa}$ was observed compared with control as shown in Fig. 2A. The product of recombinant cecropinXJ was mainly present in the supernatant of bacterial lysate following ultrasonic cell lysis and the output was $\sim 30 \%$ of the total bacterial proteins. Purification of recombinant cecropinXJ proteins by Ni-NTA resulted in the isolation of $\sim 10 \mathrm{mg}$ protein/l of culture (Table I). The specific binding of the His-tag to cecropinXJ was revealed by western blot analysis (Fig. 2B).

Assay of antimicrobial activity. To confirm that cecropinXJ has an inhibitory effect against several pathogenic bacterial 
Table II. Antimicrobial activity of cecropinXJ.

\begin{tabular}{lc}
\hline Microorganisms & $\mathrm{MIC}(\mu \mathrm{M})^{\mathrm{a}}$ \\
\hline Gram-negative bacteria & \\
Klebsiella pneumoniae & 0.8 \\
Shigella flexneri & 2.4 \\
Acinetobacter baumannii & 4.8 \\
Shigella sonnei & 2.4 \\
Klebsiella ozaenae & 3.6 \\
Gram-positive bacteria & \\
Staphylococcus aureus & 0.4 \\
Enterococcus faecalis & 1.2 \\
Staphylococcus epidermidis & 2.4 \\
\hline
\end{tabular}

${ }^{\text {aT }}$ These concentrations represent mean values of three independent experiments performed in duplicate. MIC, minimum inhibitory concentration.

Table III. Antifungal activity of cecropinXJ.

\begin{tabular}{lc}
\hline Fungus & MIC $(\mu \mathrm{M})^{\mathrm{a}}$ \\
\hline Alternaria alternata & 25 \\
Penicillium digitatum & 1.56 \\
Botrytis cinerea & 6.25 \\
Rhizopus stolonifer & 12.5 \\
Penicillium italicum & 6.25 \\
Magnaporthe grisea & 0.78 \\
\hline \multirow{2}{*}{ These concentrations represent mean values of three independent } \\
experiments performed in duplicate. MIC, minimum inhibitory con- \\
centration.
\end{tabular}

strains, antimicrobial assays were performed as listed in Table II. The purified cecropinXJ showed strong antimicrobial activity against the tested strains (Fig. 3). Of the tested strains, Staphylococcus aureus was the most sensitive to cecropinXJ whereas Acinetobacter baumannii was not sensitive to this antimicrobial peptide. CecropinXJ inhibited $S$. aureus activity with an MIC of $0.4 \mu \mathrm{M}$.

Assay of antifungal activity. The inhibition zone assay is a simple method for estimating lethal concentrations. However, for certain filamentous fungi, the diameters of the inhibition zones were poorly defined, and for this reason we used a microplate assay to observe the antifungal activity of cecropinXJ under a microscope. As shown in Table III, the MICs of cecropinXJ for A. alternata, $P$. digitatum, $B$. cinerea, $R$. stolonifer, $P$. italicum and $M$. grisea were $25,1.56,6.25,12.5,6.25$ and $0.78 \mu \mathrm{M}$, respectively. CecropinXJ displayed strong antifungal activity against all the tested fungi and fungal growth was completely blocked by cecropinXJ at micromolar concentrations.

Temperature and $p H$ stability. The results of the heat stability assay confirmed that cecropinXJ was fully heat stable as the

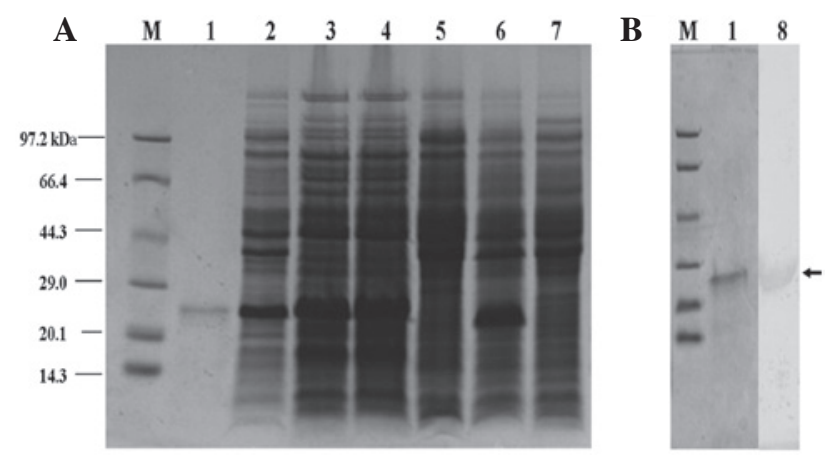

Figure 2. Expression of pET32a-cecropinXJ fusion protein analyzed by Tricine-SDS-PAGE. Lane M: Protein molecular mass marker; lane 1: purified pET32a-cecropinXJ; lane 2: precipitation of bacterial lysate; lane 3: supernatant of bacteriallysate; lane 4: induced BL21(DE3)-pET32a-cecropinXJ $\left(37^{\circ} \mathrm{C}\right.$, $0.8 \mathrm{mM}$ IPTG, 5 h); lane 5:uninduced BL21(DE3)-pET32a-cecropinXJ; lane 6: induced BL21(DE3)-pET32a; lane 7: induced BL21(DE3); lane 8: western blot of purified pET32a-cecropinXJ. IPTG, isopropyl- $\beta$-D-thiogalactoside.

A

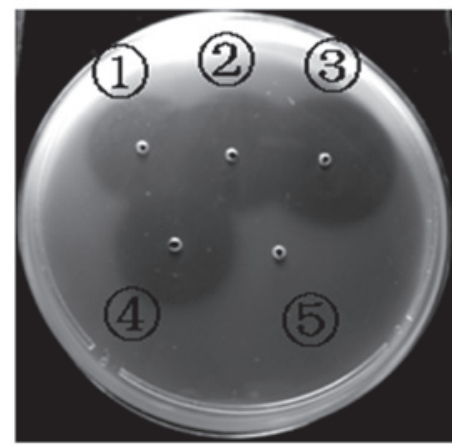

B

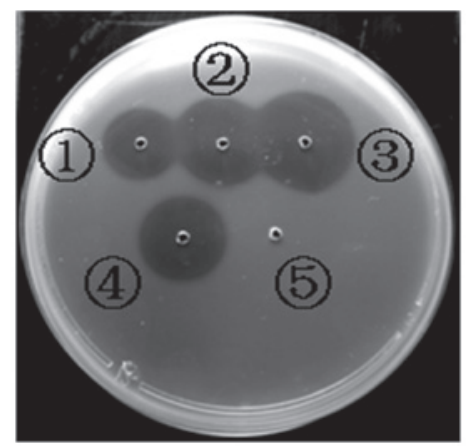

Figure 3. Antimicrobial activity of recombinant cecropinXJ and ampicillin using inhibition zone assays. (A) Gram-positive bacterium Staphylococcus aureus treated with (1-3), 1,2 and $5 \mu \mathrm{M}$ purified cecropinXJ, respectively; (4), $0.5 \mu \mathrm{M}$ ampicillin; (5), $10 \mu 1$ sterile, deionized water. (B) Gram-negative bacterium Klebsiella penumoniae treated with (1-3), 1, 2 and $5 \mu \mathrm{M}$ purified cecropinXJ, respectively; (4), $0.5 \mu \mathrm{M}$ ampicillin; (5), $10 \mu \mathrm{l}$ sterile, deionized water.

antimicrobial activity of cecropinXJ toward $S$. aureus was retained, even following exposure to $100^{\circ} \mathrm{C}$ for $12 \mathrm{~h}$ (Fig. 4A). CecropinXJ was also observed to be stable at a wide range of $\mathrm{pH}$ values as the antimicrobial activity of cecropinXJ was retained between $\mathrm{pH} 2.0$ to 10.0. However, the antimicrobial activity of cecropinXJ was reduced significantly at $\mathrm{pH} \geq 10.0$ (Fig. 4B). All assays were performed in duplicate.

Hemolysis assays. To examine whether cecropinXJ had hemolytic activity, we tested its ability to lyse erythrocytes. 

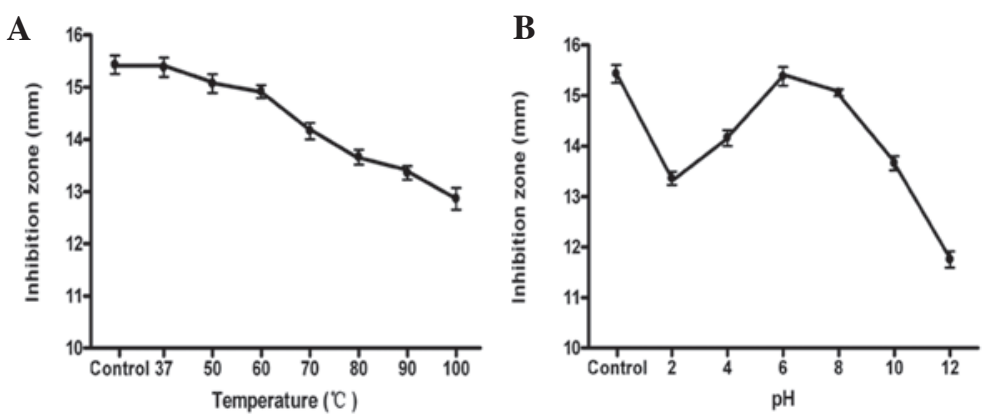

Figure 4. Effects of (A) temperature and (B) $\mathrm{pH}$ on cecropinXJ. The controls used were (A) cecropinXJ kept at $4{ }^{\circ} \mathrm{C}$ and (B) cecropinXJ in the original culture $(\mathrm{pH} 7)$. Staphylococcus aureus was used as the indicator strain.

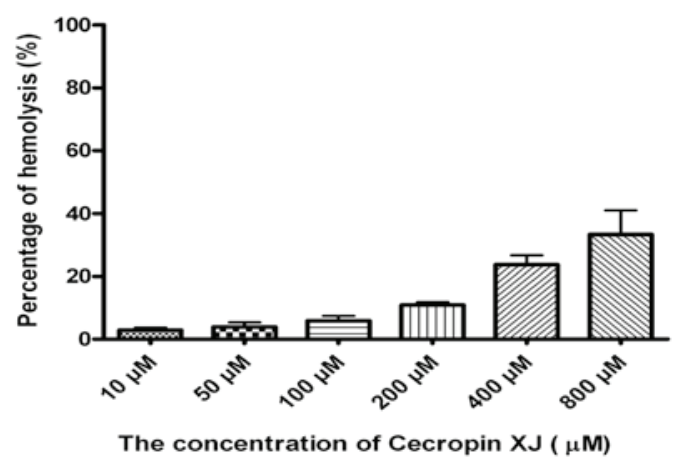

Figure 5. In vitro hemolytic activity of cecropin XJ on human erythrocytes. Controls for $0 \%$ hemolysis (blank) and $100 \%$ hemolysis were determined in phosphate-buffered saline (PBS) and 1\% Triton X-100, respectively. Values shown are the means of three independent experiments performed on different occasions with error bars representing standard deviations.

CecropinXJ had little hemolytic activity on red blood cells, even at peptide concentrations of up to $200 \mu \mathrm{M}$ (Fig. 5).

Cell proliferation and viability assay. MTT results showed that cecropinXJ inhibited the proliferation of several cancer cells within $0.01-0.5 \mu \mathrm{M}$ in a concentration-dependent manner. No inhibition of the proliferation of normal human embryonic kidney epithelial cells was observed (Fig. 6).

\section{Discussion}

AMPs exhibit significant antibacterial activity against Gram-positive and Gram-negative bacteria, and also have potent antitumor activities, which have been studied extensively and are among the most promising candidates for pharmaceutical and antiseptic use $(4,7)$. The difficult isolation and purification processes of the native antimicrobial peptides from their natural sources, as well as the relatively high costs of chemical synthesis, have limited their wide application (23). The ability to produce larger quantities of highly bioactive AMPs at low cost via recombinant DNA technology is important (24). The E. coli recombinant expression system is a suitable choice for large-scale production, due to its easy culture, fast growth and effective prevention of bacterial contamination (25). Numerous AMPs have been

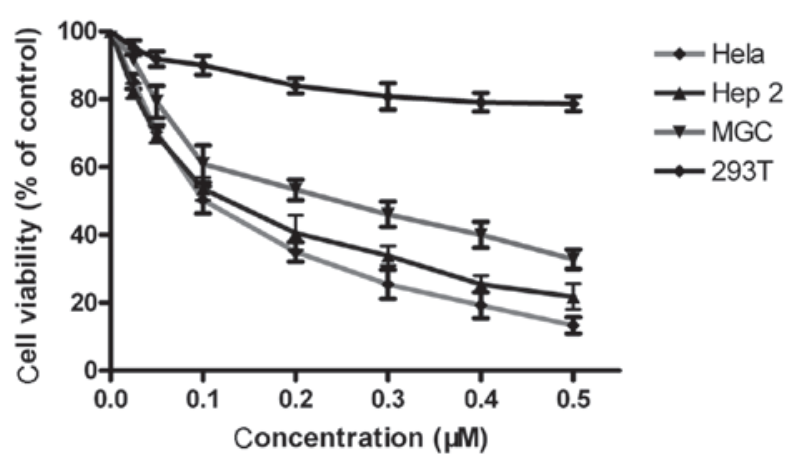

Figure 6. Determination of cell viability by MTT assay. Various cell lines were treated with cecropinXJ in concentrations ranging from 0.01 to $0.5 \mu \mathrm{M}$ and cell viability was measured by MTT assay. HeLa (human cervical cancer), Hep2 (human laryngeal cancer), MGC (human gastric cancer) and 293T (human embryonic kidney epithelial) cells were cultured in RPMI-1640 medium supplemented with $10 \%$ FCS for $24 \mathrm{~h}$ at $37^{\circ} \mathrm{C}$. Data are expressed as mean \pm SEM from three independent experiments

prepared successfully in E. coli, including brevinin-2R (26) and palusterin-2CE (27). A number of fusion partners have been used to express AMPs, including maltose-binding protein, thioredoxin and green fluorescent protein (28-30), to avoid toxicity and proteolysis of AMPs and increase their expression levels in E. coli $(17,24)$.

An antimicrobial peptide expressed in bacteria may be cytotoxic to the host or subjected to degradation by host-derived peptidases $(24,31)$. To overcome these potential problems, we fused the DNA coding sequence of a cecropinXJ gene analog within the sequence of a bacterial thioredoxin gene, which was expressed in the pET32a $(+)$ expression system under optimized conditions $(15,32)$.

In a previous study, culture and induction conditions were demonstrated to affect the expression of the soluble target proteins (24). The highest level of soluble expression was achieved at $37^{\circ} \mathrm{C}$ and $0.8 \mathrm{mM}$ IPTG with a yield reaching $30-35 \%$ of the total bacterial proteins (Fig. 1), which was higher than for other AMPs, including adenoregulin (33), perinerin (34), brevinin-2R (26) and ranalexin (35), which had yields of 20, 20-25, 25 and 23-28\%, respectively. Subsequently, purification was relatively simple and efficient for preparing large quantities of fusion proteins by affinity chromatography. The yield of cecropinXJ fusion protein reached $10 \mathrm{mg} / \mathrm{l}$ of bacterial culture. By comparison of the expression of cecropinXJ with that of other cecropin peptides (36-39), the 
fusion technology may be employed as a new method for the production of recombinant cecropin peptides.

The recombinant cecropinXJ demonstrated potent antimicrobial activity and a broad antimicrobial spectrum against Gram-positive and Gram-negative bacteria (Table II) and against fungi (Table III). In addition, cecropinXJ retained a high stability against $S$. aureus under different temperatures ranging from 4 to $100^{\circ} \mathrm{C}$ and $\mathrm{pH}$ values ranging from $\mathrm{pH} 3.0$ to 12.0 (Fig. 4). Earlier studies had indicated that cecropinXJ shares a similar structure with ABP-CM4, which has the ability to form specific amphipathic $\alpha$-helices which allows targeting of nonpolar lipid cell membranes. Upon membrane targeting, the helices form ion-permeable channels, subsequently resulting in cell depolarization, irreversible cytolysis and finally cell death (40-42).

A previous study observed that short cationic peptides consisting of arginine, leucine and lysine inhibit the proliferation of certain types of tumor cells, but do not affect normal cells (43). Differences between the membranes of tumor cells and normal cells contribute to the selectivity of antimicrobial peptides for tumor cells (44-46). In addition, the amphipathic helix of cecropinXJ may play an important role in killing cancer cells by causing leakage of the biomembranes and cytoskeleton. Due to their selectivity, this type of peptide is a good candidate for development as an antitumor agent.

In summary, we provided a simple, economical strategy for producing the antimicrobial peptide cecropinXJ without affecting its antimicrobial activity. Recombinant antibacterial peptide cecropinXJ shows potent activities against bacteria, fungi and tumor cells, and may be a promising candidate for use as a new antibiotic. Furthermore, this study provides a basis for the pharmaceutical application of cecropinXJ.

\section{Acknowledgements}

This study was supported by a grant from the high-tech Research and Development Program of Xinjiang (No.201110101).

\section{References}

1. Boman HG: Peptide antibiotics and their role in innate immunity. Annu Rev Immunol 13: 61-92, 1995.

2. Zasloff M: Antimicrobial peptides of multicellular organisms. Nature 415: 389-395, 2002.

3. Devine DA and Hancock RE: Cationic peptides: distribution and mechanisms of resistance. Curr Pharm Des 8: 703-714, 2002.

4. Brouwer CP, Rahman M and Welling MM: Discovery and development of a synthetic peptide derived from lactoferrin for clinical use. Peptides 32: 1953-1963, 2011.

5. Ribeiro MM, Franquelim HG, Torcato IM, Ramu VG, Heras M, Bardaji ER and Castanho MA: Antimicrobial properties of analgesic kyotorphin peptides unraveled through atomic force microscopy. Biochem Biophys Res Commun 420: 676-679, 2012.

6. Mei HF, Jin XB, Zhu JY, Zeng AH, Wu Q, Lu XM, Li XB and Shen J: $\beta$-Defensin 2 as an adjuvant promotes anti-melanoma immune responses and inhibits the growth of implanted murine melanoma in vivo. PLoS One 7: e31328, 2012.

7. Wu Y, He Y and Ge X: Functional characterization of the recombinant antimicrobial peptide Trx-Ace-AMP1 and its application on the control of tomato early blight disease. Appl Microbiol Biotechnol 90:1303-1310, 2011.

8. Boman HG, Wade D, Boman IA, Wåhlin B and Merrifield RB: Antibacterial and antimalarial properties of peptides that are cecropin-melittin hybrids. FEBS Lett 259: 103-106, 1989.

9. Moore AJ, Devine DA and Bibby MC: Preliminary experimental anticancer activity of cecropins. Pept Res 7: 265-269, 1994.
10. Hancock RE and Lehrer R: Cationic peptides: a new source of antibiotics. Trends Biotechnol 16: 82-88, 1998.

11. Yamaguchi Y and Ouchi Y: Antimicrobial peptide defensin: Identification of novel isoforms and the characterization of their physiological roles and their significance in the pathogenesis of diseases. Proc Jpn Acad Ser B Phys Biol Sci 88: 152-166, 2012.

12. Niu M, Li X, Wei J, Cao R, Zhou B and Chen P: The molecular design of a recombinant antimicrobial peptide $\mathrm{CP}$ and its in vitro activity. Protein Expr Purif 57: 95-100, 2008.

13. Lee SB, Li B, Jin S and Daniell H: Expression and characterization of antimicrobial peptides Retrocyclin-101 and Protegrin-1 in chloroplasts to control viral and bacterial infections. Plant Biotechnol J 9: 100-115, 2011.

14. Wang X, Zhu M, Yang G, Su C, Zhang A, Cao R and Chen P: Expression of cecropin B in Pichia pastoris and its bioactivity in vitro. Exp Ther Med 2: 655-660, 2011.

15. Feng X, Liu C, Guo J, Song X, Li J, Xu W and Li Z: Recombinant expression, purification, and antimicrobial activity of a novel hybrid antimicrobial peptide LFT33. Appl Microbiol Biotechnol 95: 1191-1198, 2012.

16. Yamada K, Nakajima Y and Natori S: Production of recombinant sarcotoxin IA in Bombyx mori cells. Biochem J 272: 633-636, 1990.

17. Zorko M and Jerala R: Production of recombinant antimicrobial peptides in bacteria. Methods Mol Biol 618: 61-76, 2010.

18. LaVallie ER, Diblasio EA, Kovacic S, Grant KL, Schendel PF and McCoy JM: A thioredoxin gene fusion expression system that circumvents inclusion body formation in E. coli cytoplasm. Biotechnology (NY) 11: 187-193, 1993.

19. Li JY, Zhang FC and Ma ZH: Prokaryotic expression of cecropin gene isolated from the silk worm Bombyx mori Xinjiang race and antibacterial activity of fusion cecropin. Acta Entomol Sin 47: 407-411, 2004 (In Chinese)

20. Tang X, Wang H, Kelaimu R, Mao XF and Liu ZY: Molecular cloning, expression of cecropin-XJ gene from silkworm and antibacterial activity in Pichia pastoris. Biotechnology 21: 26-31, 2011 (In Chinese)

21. Wang Y, Hong J, Liu X, Yang H, Liu R, Wu J, Wang A, Lin D and Lai R: Snake Cathelicidin from Bungarus fasciatus is a potent peptide antibiotics. PLoS ONE 3: e3217, 2008.

22. Bignami GS: A rapid and sensitive hemolysis neutralization assay for palytoxin. Toxicon 31: 817-820, 1993.

23. Monincová L, Budesínský M, Slaninová J, Hovorka O, Cvacka J, Voburka Z, Fucík V, Borovicková L, Bednárová L, Straka J and Cerovský V: Novel antimicrobial peptides from the venom of the eusocial bee Halictus sexcinctus (Hymenoptera: Halictidae) and their analogs. Amino Acids 39: 763-775, 2010.

24. Ingham AB and Moore RJ: Recombinant production of antimicrobial peptides in heterologous microbial systems. Biotechnol Appl Biochem 47: 1-9, 2007.

25. Huang L, Leong SS and Jiang R: Soluble fusion expression and characterization of bioactive human beta-defensin 26 and 27. Appl Microbiol Biotechnol 84: 301-308, 2009.

26. Mehrnejad F, Naderi-Manesh H, Ranjbar B, Maroufi B, Asoodeh A and Doustdar F: PCR-based gene synthesis, molecular cloning, high level expression, purification, and characterization of novel antimicrobial peptide, brevinin-2R, in Escherichia coli. Appl Biochem Biotechnol 149: 109-118, 2008.

27. Sun Y, Li Q, Li Z, Zhang Y, Zhao J and Wang L: Molecular cloning, expression, purification, and functional characterization of palustrin-2CE, an antimicrobial peptide of Rana chensinensis. Biosci Biotechnol Biochem 76: 157-162, 2012.

28. Kapust RB and Waugh DS: Escherichia coli maltose-binding protein is uncommonly effective at promoting the solubility of polypeptides to which it is fused. Protein Sci 8: 1668-1674, 1999.

29. Xu X, Jin F, Yu X, Ji S, Wang J, Cheng H, Wang C and Zhang W: Expression and purification of a recombinant antibacterial peptide, cecropin, from Escherichia coli. Protein Expr Purif 53: 293-301, 2007.

30. Yu F, Wang J, Zhang P, Hong Y and Liu W: Fusion expression of cecropin B-like antibacterial peptide in Escherichia coli and preparation of its antiserum. Biotechnol Lett 32: 669-673, 2010.

31. Cabral KM, Almeida MS, Valente AP, Almeida FC and Kurtenbach E: Production of the active antifungal Pisum sativum defensin 1 (Psd1) in Pichia pastoris: overcoming the inefficiency of the STE13 protease. Protein Expres Purif 31: 115-122, 2003.

32. Zhou L, Zhao Z,Li B, Cai Y and Zhang S: TrxA mediating fusion expression of antimicrobial peptide CM4 from multiple joined genes in Escherichia coli. Protein Expr Purif 64: 225-230, 2009. 
33. Cao W, Zhou Y, Ma Y, Luo Q and Wei D: Expression and purification of antimicrobial peptide adenoregulin with C-amidated terminus in Escherichia coli. Protein Expr Purif 40: 404-410, 2005.

34. Zhou QF, Luo XG, Ye L and Xi T: High-level production of a novel antimicrobial peptide perinerin in Escherichia coli by fusion expression. Curr Microbiol 54: 366-370, 2007.

35. Aleinein RA, Hamoud R, Schäfer $H$ and Wink M: Molecular cloning and expression of ranalexin, a bioactive antimicrobial peptide from Rana catesbeiana in Escherichia coli and assessments of its biological activities. Appl Microbiol Biotechnol Oct 4, 2012 (Epub ahead of print).

36. Skosyrev VS, Kulesskiy EA, Yakhnin AV, Temirov YV and Vinokurov LM: Expression of the recombinant antibacterial peptide sarcotoxin IA in Escherichia coli cells. Protein Expr Purif 28: 350-356, 2003.

37. Chen X, Zhu F, Cao Y and Qiao S: Novel expression vector for secretion of cecropin AD in Bacillus subtilis with enhanced antimicrobial activity. Antimicrob Agents Chemother 53: 3683-3689, 2009

38. Zhou L, Lin Q, Li B, Li N and Zhang S: Expression and purification the antimicrobial peptide CM4 in Escherichia coli. Biotechnol Lett 31: 437-441, 2009.

39. Wang H, Meng XL, Xu JP, Wang J, Wang H and Ma CW: Production, purification and characterization of the cecropin from Plutella xylostella, pxCECA1, using an intein-induced self-cleavable system in Escherichia coli. Appl Microbiol Biotechnol 94: 1031-1039, 2012.
40. Pokorny A, Kilelee EM, Wu D and Almeida PF: The activity of the amphipathic peptide delta-lysin correlates with phospholipid acyl chain structure and bilayer elastic properties. Biophys J 95: 4748-4755, 2008.

41. Wimley WC: Describing the mechanism of antimicrobial peptide action with the interfacial activity model. ACS Chem Biol 5: 905-917, 2010.

42. Rausch JM, Marks JR, Rathinakumar R and Wimley WC: Beta-sheet pore-forming peptides selected from a rational combinatorial library: mechanism of pore formation in lipid vesicles and activity in biological membranes. Biochemistry 46: 12124-12139, 2007.

43. Hou L, Shi Y, Zhai P and Le G: Antibacterial activity and in vitro anti-tumor activity of the extract of the larvae of the housefly (Musca domestica). J Ethnopharmacol 111: 227-231, 2007.

44. Suttmann H, Retz M, Paulsen F, Harder J, Zwergel U, Kamradt J, Wullich B, Unteregger G, Stöckle M and Lehmann J: Antimicrobial peptides of the Cecropin-family show potent antitumor activity against bladder cancer cells. BMC Urol 8: 5 , 2008.

45. Chen YQ, Min C, Sang M, Han YY, Ma X, Xue XQ and Zhang SQ: A cationic amphiphilic peptide ABP-CM4 exhibits selective cytotoxicity against leukemia cells. Peptides 31: $1504-1510,2010$

46. Cerón JM, Contreras-Moreno J,Puertollano E, de Cienfuegos GÁ, Puertollano MA and de Pablo MA: The antimicrobial peptide cecropin A induces caspase-independent cell death in human promyelocytic leukemia cells. Peptides 31: 1494-1503, 2010. 